an exception to be made in his case, and would therefore consider his motion in the same category." While he was repeating something about the unimportance of the case, dc., the Court leaned forward, extended "her" right hand and shaking "her" long forefinger in the face of the speaker, decided the motion in the following terse and vigorous style:

"No you don't, Sammy! No you don't, Sammy! This hon'ble Court has keerfully investigated that ere pint, and your motion is sustained !"

It happening that the motion covered the entire case, of course "Sammy" won.

\title{
JOHN BROWN AMONG THE PEDEE QUAKERS.
}

BY FREDERICK LLOYD.

\section{CHAPTER I.}

Thinking that whatever related to the actions of the remarkable man whose name stands at the beginning of this chapter, would have a fascinating interest, not only for his admirers but for his contemners also, we have been at some pains to glean from living witnesses the facts embraced in the following historical sketch, which having transpired within the borders of Iowa, and within a few miles of where the State Historical Society hold their sittings, makes their publication in this work exceedingly appropriate.

Fifteen miles east and a little north of Iowa City, sits the quiet little village of Springdale, the center of what is known abroad as the Pedee or Quaker settlement of Cedar County, though in point of fact the locality known in Cedar County as the Pedee Settlement proper, and which is in Iowa township, contains but a comparatively small number of Quakers, who abound more in the adjoining township of Springdale, in which the village of that name is situated. Five miles west of Springdale, in the same township, is Wost Branch, and two 12 
miles east, in Iowa township, Pedee Post Office and villageplaces in size and importance less pretending than Springdale, which, besides being supplied with a Post Office, supports a store devoted to geueral merchandize, a carriage and blacksmith shop, a school-house and a meeting-house, and has a population of about ono hundred souls.

The Pedee Settlement so called, which derives its name from a small creek to which the earlier settlers who built their first log-cabins on its banks gave the name of Pedee, is largely composed of adherents to the Society of Friends, who, dwelling in comfortable houses, surrounded by their own teeming fields, and enjoying to the utmost the fruits of virtuous liberty and their own thrift, would gladly see all men in the possession of the same blessings God has showered upon them.

The traveler who, driving through Springdale of a hot summer's day, draws up at the delicious spring, refreshing himself from the tin dipper and his horse from the wooden bucket there confidingly kept for the public benefit,- the christian atmosphere of the place being a sufficient guarantee for their safety,- does not see in the trim, well painted frame cottages, faced by neat blue-grass front yards, that line each side of the high-way, nor in the broad-brimmed hats and scuttle-shaped bonnets that bob about, nor in any other feature of this placid and orderly little place, the least ground for speculation that here might have been conceived and planned the wildest and boldest project that ever infatuated the mind of man, and which, under the providence of God, was ordained as the prelude to events which shook all the world and loosened the fetters of a whole race.

The persons who harbored, and with money and counsel, assisted John Brown on the several occasions he visited Iowa City and the Pedee Settlement, and to whom we are indebted for the facts of this imperfectly written narrative, are citizens of the highest respectability, and some of them of the most eminent standing, as will be seen when we come to mention 
their names in their appropriate order, and they all, though tar from approving the chief act of his life which has made Brown's name historic, believe him to have been actuated by the highest and most disinterested motives. To some of his friends Brown confided the outline of his plan of operations, which finally culminated in the Harper's Ferry raid, but these disclosures were looked upon at the time as emanating from the transitory mental disturbances of an excited visionary, and as unworthy of more than passing attention. These gentlemen, in what they did toward assisting Brown and the fugitive slaves he piloted through Iowa to a land of freedom, took counsel of their consciences and God's command to "hide, the outcast."

The personal appearance of Brown is sufficiently familiar to the public to relieve us from the necessity of giving a particular description of it. He was five feet ten inches in height, weighed about 150 pounds, was wiry and muscular, wore a home-spun coat and a long white beard. He had a stoop in his shoulders, and in general appearance resembled an old Pennsylvania Dutch farmer.

Some have attributed insanity to Brown, but we must recollect that Gallileo, Columbus and General Sherman had the credit of being crazy. There can be no doubt that Brown sincerely and religiously believed it to be his mission to make war upon slavery. It may do in our day to say that he was infatuated, but a later generation will say that he was inspired. $\mathrm{He}$ frequently said that he had a commission from the Almighty to free slaves. To the Hon. J. B. Grinnell, (one of those who afforded to Brown and his fugitive parties shelter and food, he spoke in a prophetic way of great events in the future. When asked to be specific, he said, "time will tell it." In his early years Brown had become a member of the masonic order, and had studied for the Presbyterian ministry, but for thirty years before his death, he had been studying the art of war, and for this purpose had traveled over Europe examining the different systems of fortification there. $\mathrm{He}$ 
had also been a careful reader of history, and had paused with satisfaction at the name of Leonidas and the story of the pass of Thermopylæ. He was generally silent except with those who had his entire confidence, with whom he talked freely. Stevens and Kagi were the only ones of his immediate party to whom he confided, usually, his intended movements. His men had the fullest confidence in him, and were always willing, without question, to perform his bidding. $\mathrm{He}$ always disclaimed the desire to shed blood, but thought that by making frequent raids into the heart of the slave territory, he would in time awaken the people of the South to a sense of the insecurity of their favorite institution, and thus induce them to abolish it. He was not cruel, and the story of his compelling prisoners to go down on their knees to him, we are assured, on the best authority, is a sheer fabrication. In religious views, he was very tolerant, as is shown by the fact of nearly all his band differing from him in religious sentiment, He only asked his men to do what they knew to be right. He urged none to join his standard--only saying that if any believed as he did, he would be glad to have their assistance in freeing slaves. The key to Brown's actions must probably be looked for in his excessive benevolence, which led him to desire to see all men enjoy the same blessings he himself possessed, united to a combative disposition, which impelled him to attempt an enforcement of his wish.

It was about the close of the Presidential campaign in $\mathbf{1 8 5 6 ,}$ that Brown first visited Iowa City and the Pedee Settlement. He was then on his way east from Kansas, and was accompanied by one of his sons. The Hon. W. Penn. Clarke, (now Colonel and Paymaster in the army,) was the member of the Kansas National Committee for Iowa, and his residence being at Iowa City, made this town the chief headquarters west of the Mississippi for those who sympathized with the Free State men of Kansas. To this point, money, arms, clothing and other supplies were forwarded for distribution to those who were fighting for the freedom of Kansas. Brown was thus 
brought in contact with Col. Clarke, Dr. Jesse Bowen, and other residents of Iowa City, who were in active sympathy with the Free State pioneers of Kansas.

On his journeys through Iowa, Brown was generally accompanied by fugitive slaves from Missouri, whom he and his armed band escorted through our State to a haven of freedom beyond Lake Michigan. On such oceasions Brown could always count on finding at the residence of Hon. J. B. Grinnell, in Grinnell, Poweshiek County, not only rest, food and shelter for himself and his party, white and black, but money and words of cheer besides. After leaving Grinnell, his next ark of safety was the Pedee Settlement, where he would quarter his men-passing through Iowa City in the night time to avoid molestation - and then retrace his steps to the State Capital, which Iowa City had not ceased to be yet, to consult with Clarke and other friends of the Free State morement in Kansas. On such occasions Brown generally required the benefit of a clear head and cool hundred, both of which he never failed to find at the office of Clarke, who often made up any deficiencies there might be in funds, or contributed the whole amount himself. But there were many others who gave of their means for this purpose, and even democrats, while denouncing abolitionists, were contributing their funds toward the escape of fugitive slares.

It was then, as indicated above, in the autumn of 1856 , that John Brown first visited the Pedee Settlement of Cedar County. As he alighted from his mule, (one he had captured at the battle of Black Jack, on the borders of Kansas and Missouri,) in front of the "Traveler's Rest," which was the name of the little frame tavern kept by Mr. James Townsend, in West Branch, the old man asked the landlord if he had ever heard of John Brown of Kansas notoriety, - a simple introduction, from which sprung an intimacy the closest and most confiding. The Quaker landlord thereupon proceeded to chalk. John Brown's hat and mule, and both John and his beast were ever after on the free list at the "Traveler's Rest," 
and it would have been difficult to say who was the better entertained, the guest disposing of the buckwheat eakes and sorghum of the jolly red-faced Quaker, or the host devouring the thrilling incidents of the Kansas war related by Brown. As for the mule, he liked his treatment there so well, that he continues to reside in the Pedee Settlement to this day, being now an attache of the household of Mr. John H. Painter of Springdale, and having declined, despite his former warlike employment, the tender of an eligible position in an army wagon, during the war, with five half-breed companions. The writer, having met this lncky animal in the lanes of Springdale, and noted the frisk of his tail, the flap of his ears, and his general sleek appearance, and more than all, having listened to the melodious tones of his voice, is prepared to set down as a fact in these veracious pages, that he is the most prized, petted and pampered mule in that settlementfor happiness, ease and contentment, the envy of all his fellows.

Brown was in Iowa City and the Pedee Settlement several times between his first visit in 1856 and his last in 1859 , but as the objects and incidents of these visits were similar, we omit a particular description of each, and shall confine ourselves to a somewhat minute detail of his proceedings and associations on the last two occasions he was in Iowa.

Generally these visits to Pedee had a two-fold object-the promotion of the Kansas Free-State cause and the concealment of negroes, but his last sojourns there were made chiefly with a view to perfecting his plans, accumulating arms, drilling, disciplining and recruiting his band, and taking measures for making Pedee a sort of base of operations for the raid against Harper's Ferry.

[TO BE CONTINUED.] 
Copyright of Annals of Iowa is the property of State of Iowa, by \& through the State Historical Society of Iowa and its content may not be copied or emailed to multiple sites or posted to a listserv without the copyright holder's express written permission. However, users may print, download, or email articles for individual use. 